\title{
Performance of Retarding Basin in Flood Disaster Risk Mitigation in Welang River, East Java Province, Indonesia
}

\author{
Prorida Sari \\ Agency of Public Works and Water Resources, East Java Province, Surabaya, INDONESIA \\ rida.sari29@gmail.com
}

\begin{abstract}
Flood phenomenon caused by high rainfall and sea tides on a watershed seat the tidal area, including the Welang River, commonly occur and the number of events is increasing. Construction of retarding basin is one of flood risk mitigation efforts by reducing the flood peak discharge. Assessment of flood management in Welang River was conducted with hydrology and hydraulic approaches, by using the Hydrologic Engineering Centre-Hydrologic Modelling System (HEC-HMS) 4.0 and Hydrologic Engineering Center-River Analysis System (HEC-RAS) 5.0.3 software. The hydraulic simulation consists of 4 scenarios. Scenario 1 was the current condition, while scenario 2, 3, and 4 were the retarding basin construction with one side spillway, one on the upstream (River Station (RS) 7400), on the middle (RS 6970), and on the downstream (RS 6590), respectively. The height variation of side spillways are $3 \mathrm{~m}$ and $4 \mathrm{~m}$. Flood routing simulation result showed that the existing river channel condition could not accommodate of 2-year flood and 10-year flood, which caused peak discharge of $497.7 \mathrm{~m}^{3} / \mathrm{s}$ and $794.9 \mathrm{~m}^{3} / \mathrm{s}$. At the RS 6590, the maximum runoff height of 2-year and 10-year flood were 0.66 and $1.02 \mathrm{~m}$, respectively. Under the 2-year return period of flood, the discharge reduction caused by the retarding basin at control point RS 5341.4 (Karangketug Village), were $39.63 \mathrm{~m}^{3} / \mathrm{s}, 31.83 \mathrm{~m}^{3} / \mathrm{s}$, and $41.93 \mathrm{~m}^{3} / \mathrm{s}$, respectively for scenario 2,3 and 4 with the $3 \mathrm{~m}$ side spillway height and $14.71 \mathrm{~m}^{3} / \mathrm{s}, 16.76 \mathrm{~m}^{3} / \mathrm{s}$, and $13.74 \mathrm{~m}^{3} / \mathrm{s}$, respectively for scenario 2,3 and 4 with the $4 \mathrm{~m}$ side spillway height.
\end{abstract}

Keyword: Welang River; retarding basin; side spillway

\section{INTRODUCTION}

Nowadays, flood on the urban area and the coastal area which caused by heavy rainfall and the sea tides have become a major concern (Shahapure, et al., 2011). Also in Indonesia, the flood phenomenon caused by high rainfall and sea tides on a watershed that disembogues to sea commonly occur and the number of events is increasing as well. This phenomenon also happens in Welang River, with the river mouth at Madura Strait. The downstream part of Welang watershed is an area that is potential to flood occurrence, particularly in Gadingrejo Sub-district, Pasuruan City, Kraton Subdistrict, and Pohjentrek Sub-district in Pasuruan Regency. In the last six years, the frequencies of flood event caused by the overflowing of Welang River were 2 to 11 times in a year. Karagketug Village, Gadingrejo Sub-district, and Pasuruan City were the locations that the most frequently suffered from flood, which were 29 times in the period of 2011 to 2016.

Frequencies of extreme flood events were increased in line with the global climate change (Milly, et al., 2002). Flood in Welang River for the last six years showed an increase in the event frequency. A study on structural and non-structural flood mitigation efforts is needed. Construction of dam as flood control is no longer a best structural effort, considering its negative impact on the environment, the high operation, and maintenance cost, and risks if structural failures occurred (Ayalew et al., 2015). New approaches to flood risk mitigation are needed by the floodplain managers to replace the large dam role. Construction on small distributed retarding basin is an approach to reduce flood risk in urban and rural areas (Verstraeten \& Poesen, 1999). Retarding basin plays a role in reducing the flood peak discharge and also increasing the water quality.

This research is aimed to find out the flow response in the downstream watershed caused by the rainfall, to find out the water level profile, and to observe the effectiveness of retarding basin in controlling the flood on Welang River.

\section{HYDROLOGY AND HYDRAULICS ROUTING}

\subsection{Hydrologic Engineering Centre-Hydrologic Modelling System (HEC-HMS)}

One of the hydrologic models that could be used to convert rainfall to flow is the HEC-HMS (Feldman, 2000). HEC-HMS is a program that was designed to simulate a complete hydrological process from a watershed system.

HEC-HMS has several facilities, such as calibration, simulation ability on the distribution model, event flow or continuous flow model (Sujono, 2014). The data required were including the area size of the watershed, 
hourly rainfall data, maximum precipitation data, and discharge data. Simulation of rainfall-runoff transformation in each sub-watershed needed several model components, which are precipitation, loss models, direct runoff, baseflow models, and routing.

HEC-HMS facilitates the model calibration process by using the Objective Function Method and Search Method (Feldman, 2000). Objective Function is an algorithm function in the program that is used to search for the model parameter that generates the most appropriate index (goodness-of-fit indices). Search Method is the method used to minimalize the objective function and gain the most optimum parameter value by iteration through trial and error process.

The objective function provided by the HEC-HMS consists of four criteria that could be chosen according to the requirement, i.e., the sum of absolute errors, the sum of squared residuals, percent error in peak, and peak weighted root mean square error objective function (Feldman, 2000).

\subsection{Hydrologic Engineering Center-River Analysis System (HEC-RAS)}

HEC-RAS is software designed for interactive use in multiple environments to model the river flow. HECRAS was made by the Hydrologic Engineering Center (HEC) under the US Army Corps of Engineers (USACE). HEC-RAS is an application program that integrates the graphical user interface feature, hydraulic analysis, data management and storing graphics, and reports (Istiarto, 2014).

\subsection{Retarding Basin}

Retarding basin is an area/pond that is used to reduce the volume and runoff peak, in which the water is retained and not being released to the downstream area, and usually gone just by infiltration through the porous base of the basin, or by evaporation. Retarding basin could also be used to support the groundwater conservation (Bedient and Huber, 1992 in Safii, 2010).

In this research, the retarding basin was planned to be placed on the right side of the river channel and equipped with side spillway without any gate. Side spillway was functioned to limit the water that went through the channel, particularly during rain events. Thus, the discharge that went through the channel could be controlled (Yuwono, 1977).

HEC-RAS facilitated modeling of the river lateral structure with side spillway overflow is approached by Equation 1 (Brunner, 2016),
$Q=C L H^{\frac{3}{2}}$

in which $C$ is the discharge coefficient, $L$ is the spillway length, $H$ is the height of energy line above the spillway crest.

\section{CONFIGURATION OF ROUTING}

\subsection{Research Location}

The area of Welang Watershed from downstream until the sea is $498.03 \mathrm{~km}^{2}$, with main river length of 40.60 $\mathrm{km}$. The water from Welang River comes from the surface water flow and groundwater flow in the area of Mount Arjuna (+ 3,200 m) and Mount Bromo $(+2,400 \mathrm{~m})$. Welang River is administratively located in Malang Regency (upstream part), Pasuruan Regency and Pasuruan City (middle part and downstream part). The Welang Watershed is included in the river basin unit (Satuan Wilayah Sungai-SWS) of Rejoso River (Figure 1).

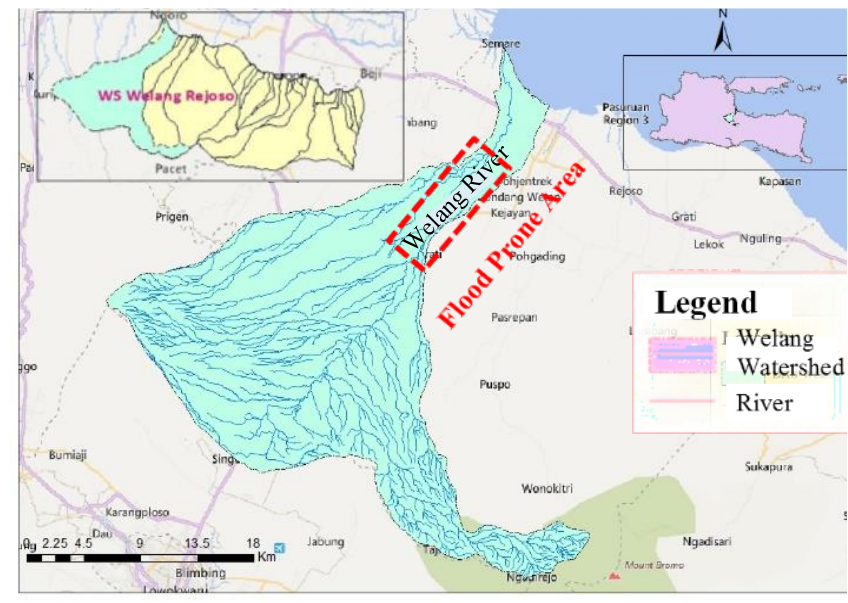

Figure 1. Research Location

\subsection{Rainfall and River Geometry Data}

The data used in this research were rainfall data and river flow data from 2003 to 2016, and flood event data from 2011 to 2016 obtained from the Office of Public Works Water Resource of East Java Province and Office of Public Works Water Resource and Spatial Planning of Pasuruan Regency. Figure 2 presents location of rain gauge stations and AWLR stations. The river geometry data was collected from the result of the measurement in 2012 (PT. Raya Konsult, 2012). The tidal data of the year 2016 was obtained from Port Authority Office and Harbourmaster of Pasuruan Regency. 


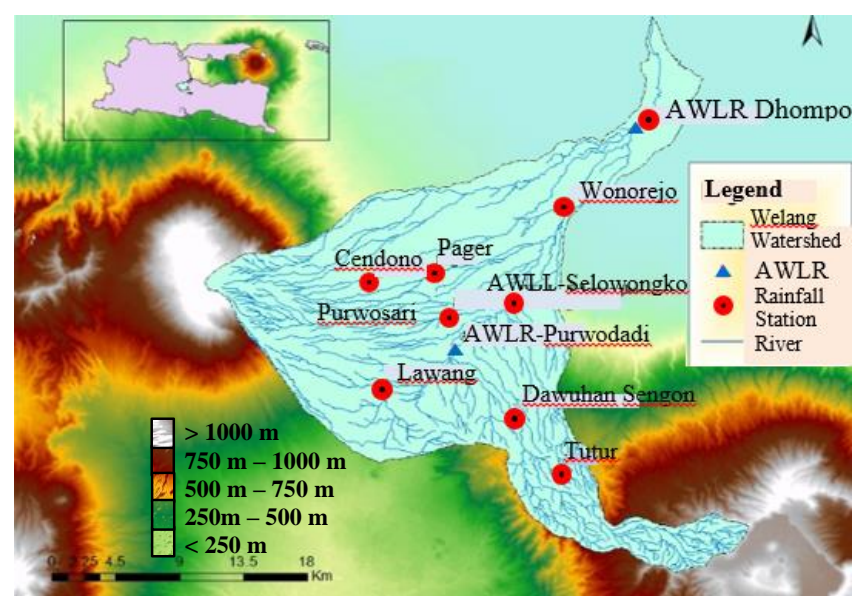

Figure 2. Location of Automatic Water Level Recorder (AWLR) and Rain Gauge Station

\subsection{Distribution of Sub-watershed}

The area of the watershed until the control point of AWLR Dhompo is $472.141 \mathrm{~km}^{2}$. Watershed area from the Welang Sub-watershed until the control point of AWLR Dhompo was divided into seven subwatersheds, as shown in Figure 3 and Table 1.

Table 1. Area of Welang Sub-watersheds

\begin{tabular}{llrr}
\hline No. & Sub-watershed & Area $\left(\mathrm{km}^{2}\right)$ & Length $(\mathrm{km})$ \\
\hline 1. & Purwodadi & 161.88 & 5.18 \\
2. & Selowongko & 103.00 & 6.39 \\
3. & Hilir Selowongko & 1.71 & 0.11 \\
5. & Curahweragan & 21.32 & 2.56 \\
4. & Grenjing & 39.28 & 5.37 \\
6. & Sumber Pinang & 47.04 & 8.91 \\
7. & Girang & 97.91 & 1.42 \\
\hline
\end{tabular}

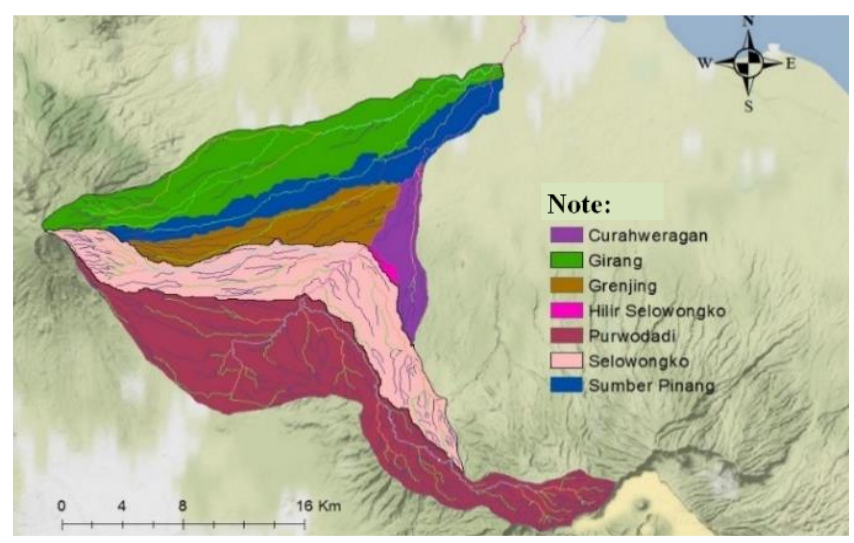

Figure 3. Welang Sub-watersheds division

\subsection{Development of Scenarios}

The scopes of this research were hydrological analysis by using the HEC-HMS version 4.0, and hydraulic analysis by using HEC-RAS version 5.0.3. Hydraulic simulation consisted of 4 scenarios, specifically, simulation with and without the retarding basin, with spillway height of $3 \mathrm{~m}$ and $4 \mathrm{~m}$, and various location of side spillway, with following details:

a) Scenario 1 was the existing condition without retarding basin,

b) Scenario 2 was a condition with retarding basin and side spillway located in the upstream area (RS 7400),

c) Scenario 3 was a condition with retarding basin and side spillway located in the middle area (RS 6970),

d) Scenario 4 was a condition with retarding basin and side spillway located in the downstream area (RS 6590).

Schemes of flow configuration for each scenario are shown in Figure 4, Figure 5, Figure 6, and Figure 7.

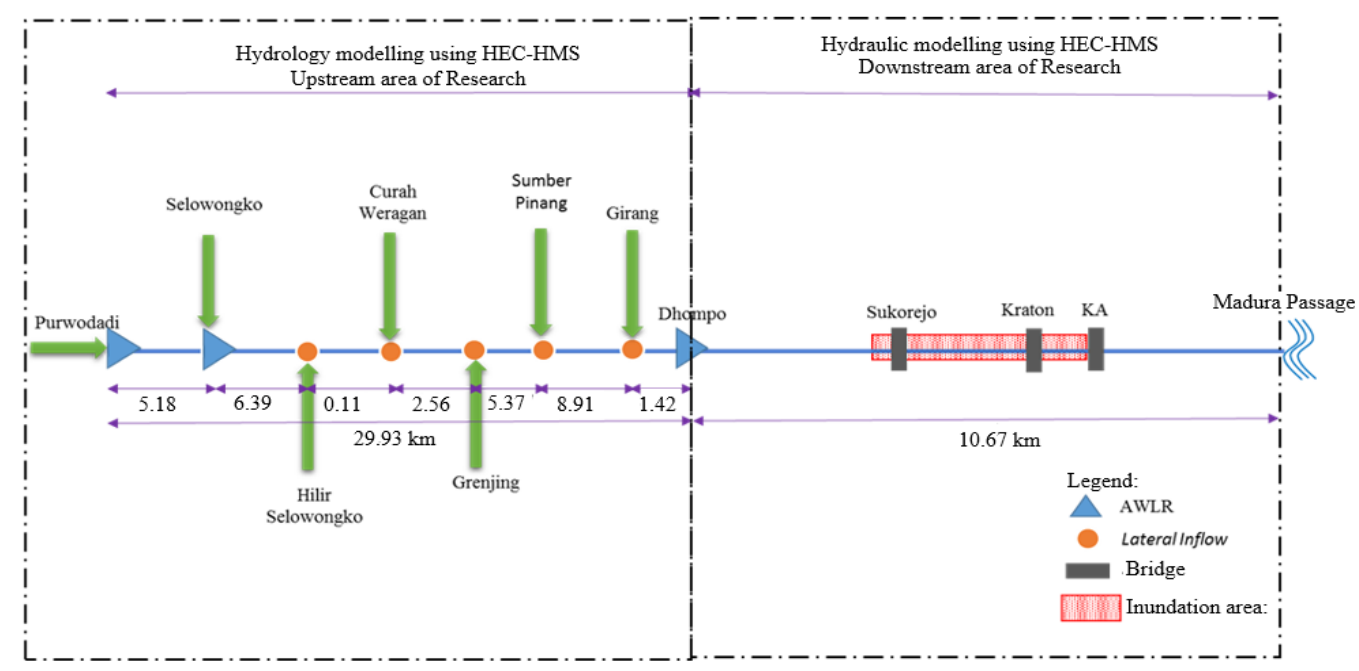

Figure 1. Scheme of flow configuration for Scenario 1 


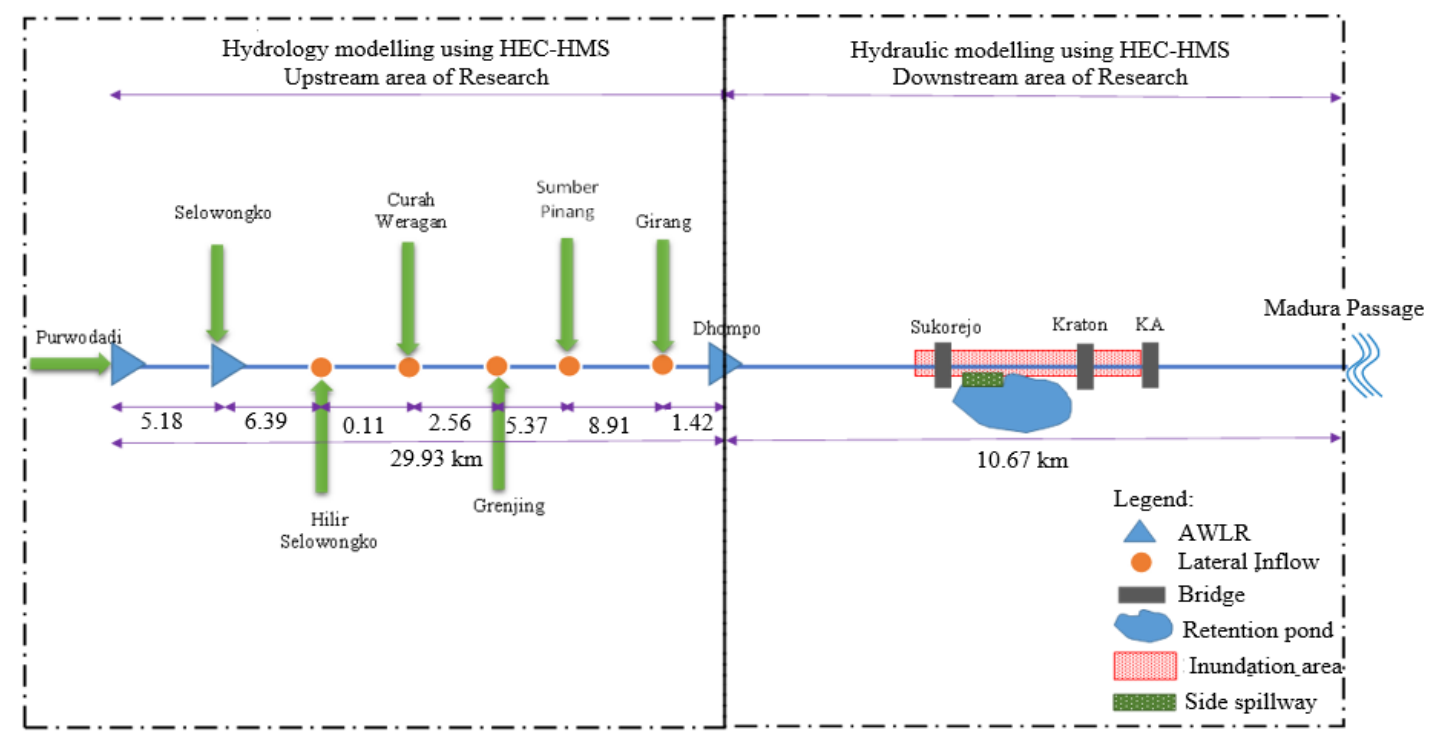

Figure 2. Scheme of flow configuration for Scenario 2

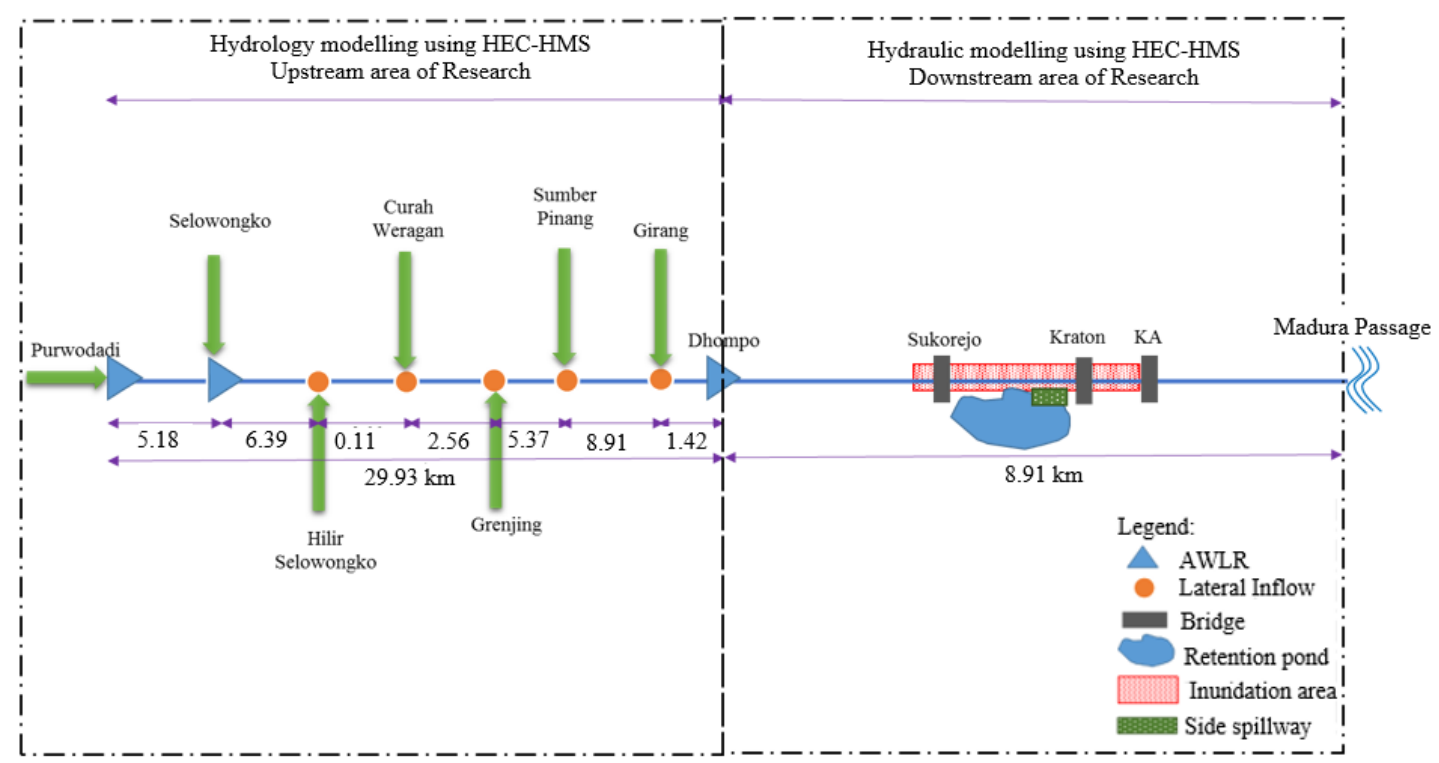

Figure 3. Scheme of flow configuration for Scenario 3

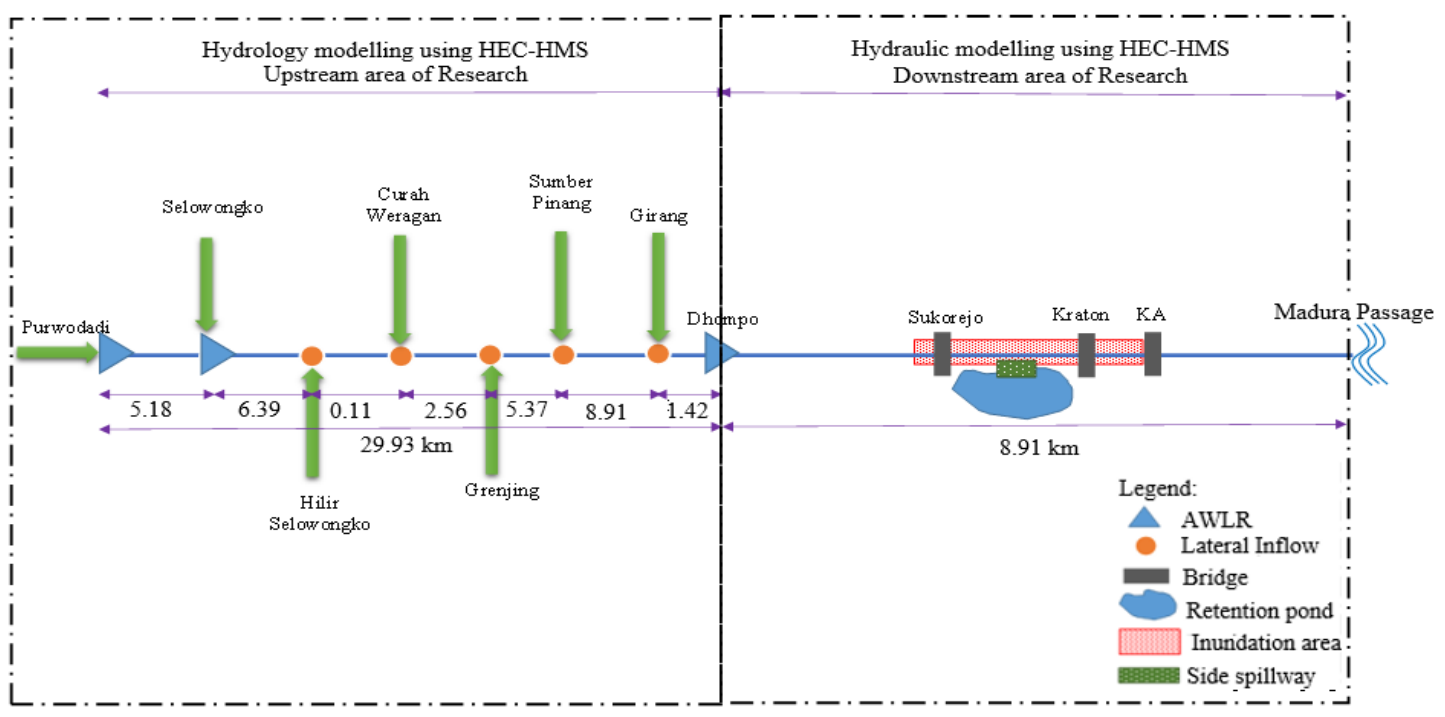

Figure 7. Scheme of flow configuration for Scenario 4 


\subsection{Rainfall Distribution}

Welang Watershed has eight manual rain gauge stations and two automatic rain gauge stations. Rainfall distribution pattern in this research was obtained by averaging the observed data Automatic Rainfall Recorder (ARR) Cendono and ARR Dawuhan Sengon, as displayed in Figure 8.

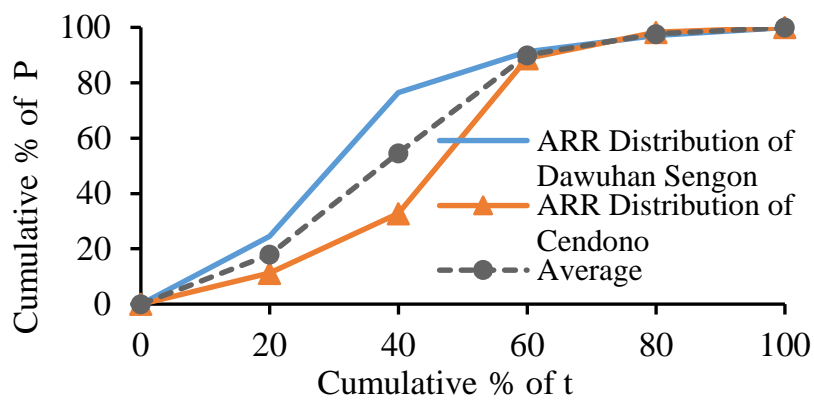

Figure 8. Rainfall distribution pattern of November $9^{\text {th }} 2016$

Based on the rainfall distribution occurred at flood event on November $9^{\text {th }}, 2016$, the dominant rainfall was inspected. It was concluded that the 6-hour rainfall duration was the rain duration that represents rain condition causing the flood. Table 5 and Figure 9 show the distribution of the dominant rainfall.

Table 5. Dominant rainfall distribution

\begin{tabular}{cccc}
\hline $\mathrm{t}$ & $\% \Sigma \mathrm{t}$ & $\% \Sigma \mathrm{P}$ & $\% \mathrm{P}$ \\
\hline 0 & 0.00 & 0.00 & 0.00 \\
1 & 16.67 & 14.91 & 14.91 \\
2 & 33.33 & 42.37 & 27.46 \\
3 & 50.00 & 72.31 & 29.94 \\
4 & 66.67 & 92.56 & 20.25 \\
5 & 83.33 & 98.06 & 5.50 \\
6 & 100.00 & 100.00 & 1.94 \\
\hline
\end{tabular}

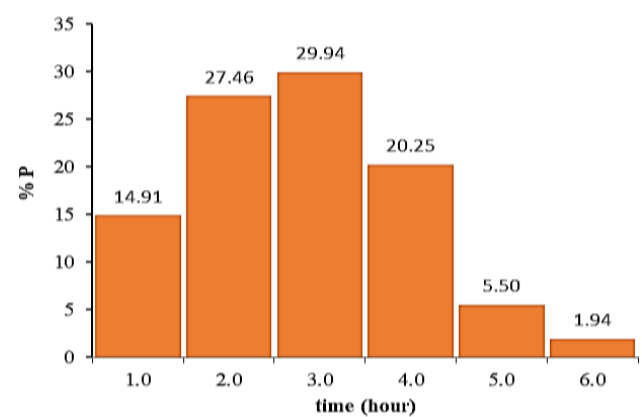

Figure 9. Hyetograph of 6-hour dominant rainfall

\subsection{Curve Number $(\mathrm{CN})$ Value}

The calculation of $\mathrm{CN}$ value was conducted to obtain the effective rain by using the Soil Conservation Service (SCS) formula. The land use map (Figure 10), and soil type map (Figure 11) were overlaid by using the Arc-GIS 10.2.2 version (Figure 12), in order to get the area weighted. The calculation result is presented in Table 6.

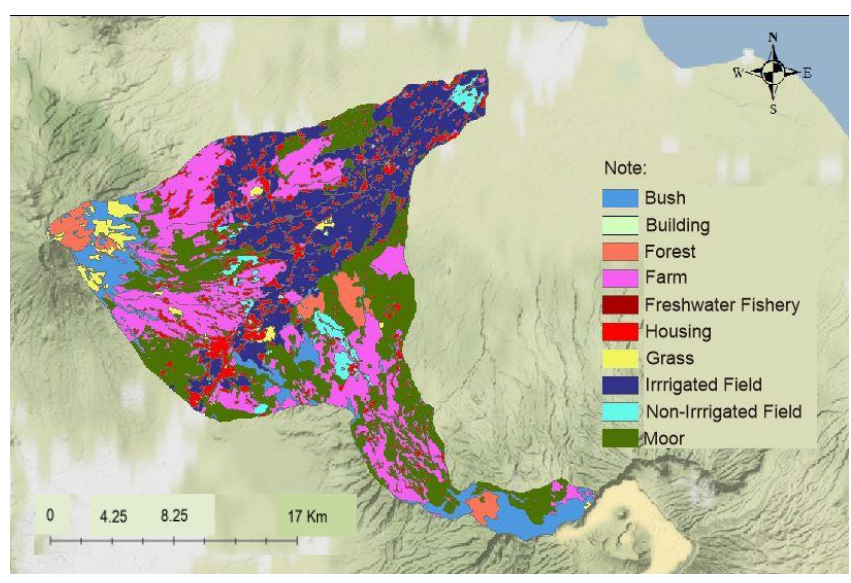

Figure 10. Land Use Map

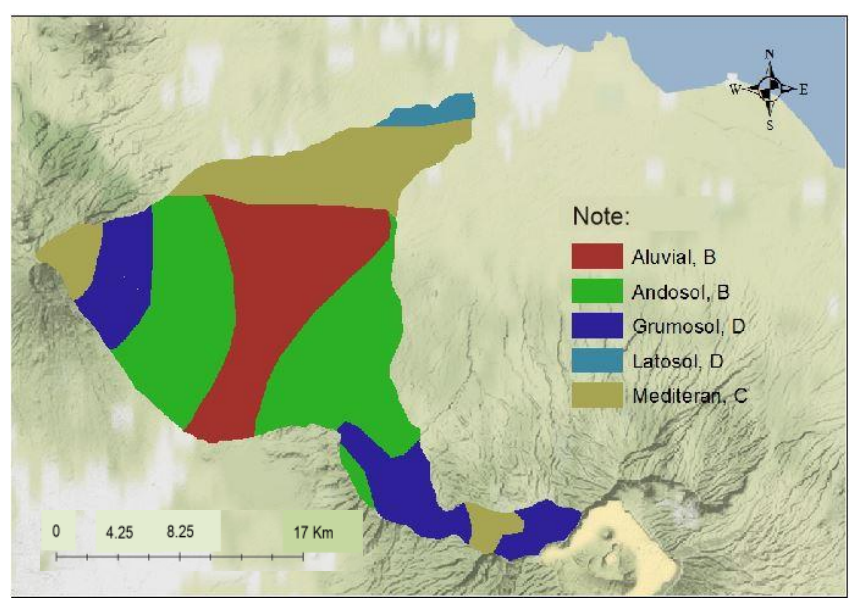

Figure 11. Map of soil types

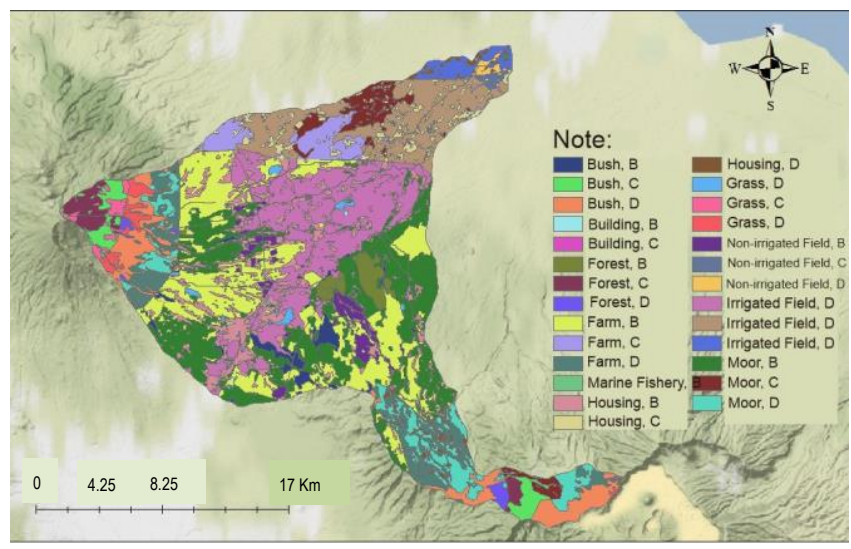

Figure 12. Overlay map of land use and soil type

Table 6. Recapitulation of CN composite value

\begin{tabular}{lllllll}
\hline \multirow{3}{*}{ Sub-watershed } & \multicolumn{3}{c}{ Normal Condition } & \multicolumn{3}{c}{ Wet Condition } \\
\cline { 2 - 7 } & CN II & $\begin{array}{l}\text { S } \\
(\mathrm{mm})\end{array}$ & $\begin{array}{l}\text { Ia } \\
(\mathrm{mm})\end{array}$ & $\begin{array}{l}\text { CN } \\
\text { III }\end{array}$ & $\begin{array}{l}\text { S } \\
(\mathrm{mm})\end{array}$ & $\begin{array}{l}\text { Ia } \\
(\mathrm{mm})\end{array}$ \\
\hline Purwodadi & 74.26 & 88.03 & 17.61 & 86.91 & 38.27 & 7.65 \\
Selowongko & 72.67 & 95.50 & 19.10 & 85.95 & 41.52 & 8.30 \\
Hilir Selowongko & 74.71 & 85.99 & 17.20 & 87.17 & 37.39 & 7.48 \\
Curah weragan & 74.71 & 85.98 & 17.20 & 87.17 & 37.38 & 7.48 \\
Grenjing & 77.85 & 72.29 & 14.46 & 88.99 & 31.43 & 6.29 \\
Sumber Pinang & 79.97 & 63.64 & 12.73 & 90.18 & 27.67 & 5.53 \\
Girang & 78.58 & 69.25 & 13.85 & 89.40 & 30.11 & 6.02 \\
\hline
\end{tabular}




\subsection{Synthetic Unit Hydrograph}

The methods used to transform rainfall into runoff were the Gama-I Synthetic Unit Hydrograph and Nakayasu Synthetic Unit Hydrograph. The Nakayasu Synthetic unit hydrograph was used in the input process of hydrologic modeling simulation with HEC-HMS in order to obtain the hydrograph of design flood discharge at the AWLR Dhompo control point. The analysis result of the Synthetic Unit Hydrograph is shown in Figure 13.

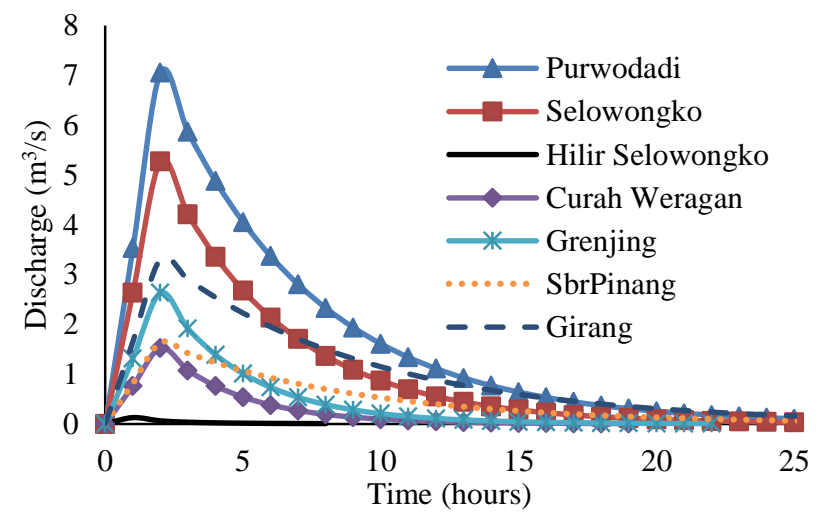

Figure 13. Synthetic Unit Hydrograph

\subsection{Hydrology Routing}

Hydrologic modeling of Welang Watershed was conducted from the upstream to the AWLR Dhompo control point at the middle part by using the HEC-HMS version 4.0. The construction of the sub-watershed scheme was shown in Figure 14, in which was followed by the modeling of main components, which were model basin, meteorology model, control specification, time series data, and paired data. These four components were watershed modeling, runoff volume, direct runoff, base flow, and flow routing.

\subsection{Calibration of Hydrology Routing}

The hydrograph of the flood event on November $9^{\text {th }}$, 2016 in AWLR Dhompo control point was made as the reference for the hydrology model calibration by using the Percent Peak Error method. Comparison between the simulation and observation is presented in Figure 15.

Parameters that measured the accuracy in optimizing the hydrograph of simulation result were the peak time $\left(t_{p}\right)$, peak discharge $\left(Q_{\mathrm{p}}\right)$, volume $(V)$, and time of center mass $\left(t_{c m}\right)$. The best result was the one with the smallest percent difference. Furthermore, the parameter resulted from the calibration process was used for the design flood analysis (see Table 10).

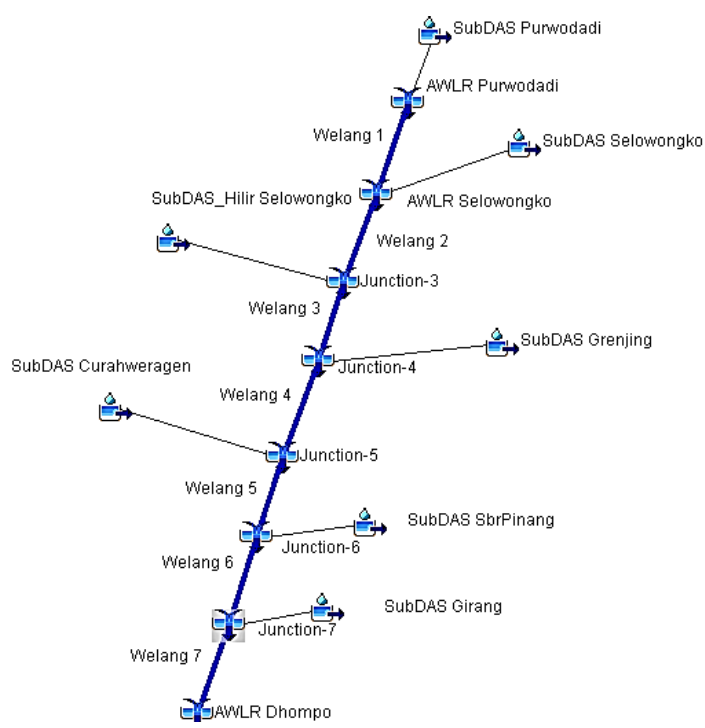

Figure 14. Scheme of Welang Watershed modeling

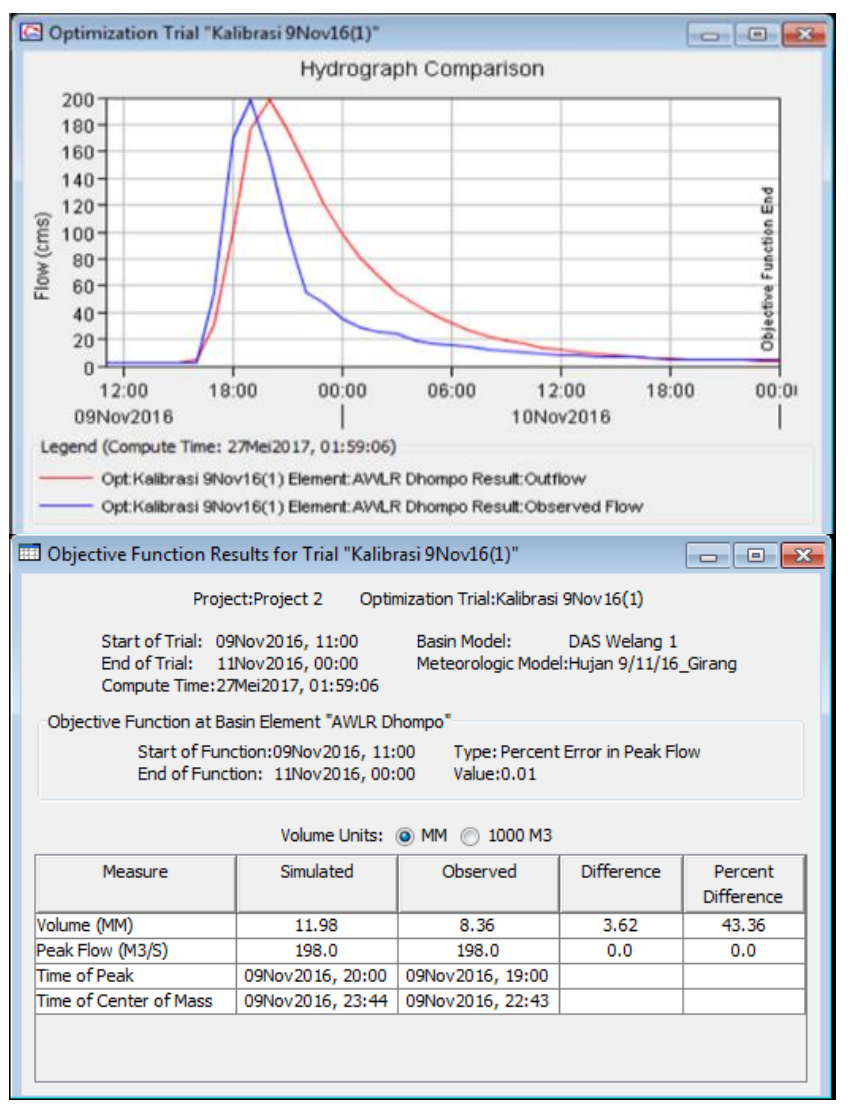

Figure 15. Calibration of flood hydrograph

Table 10. Model optimization for SCS-CN parameters

\begin{tabular}{lll}
\hline \multirow{2}{*}{ Sub-watershed } & \multicolumn{2}{l}{ Parameters } \\
\cline { 2 - 3 } & $\begin{array}{l}\text { Curve } \\
\text { Number }\end{array}$ & $\begin{array}{l}\text { Initial } \\
\text { Abstraction }\end{array}$ \\
\hline Purwodadi & 80.16 & 5.61 \\
Selowongko & 80.48 & 5.59 \\
Downstream Selowongko & 81.17 & 7.48 \\
Curah Weragan & 86.73 & 5.92 \\
Grenjing & 89.00 & 7.76 \\
Sumber Pinang & 86.17 & 5.18 \\
Girang & 79.19 & 7.48 \\
\hline
\end{tabular}




\subsection{Upstream Boundary}

The upstream boundary condition used the flood hydrograph data of AWLR Dhompo which was the control point at the initial process of hydraulic simulation. At flood event on November $9^{\text {th }}, 2016$, the water level $(h)$ hydrograph on AWLR Dhompo was recorded, as shown in Figure 16. The equation rating curve $Q=9.7198(h-0.059)^{1.95}$ resulted in flood discharge (Q) hydrograph, as shown in Figure 17, which then used as the upstream boundary condition on the calibration process.

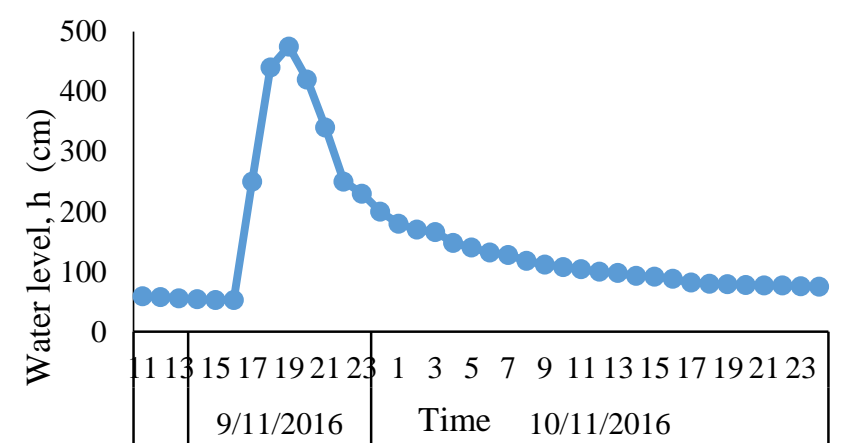

Figure 16. Water level hydrograph recorded at AWLR Dhompo

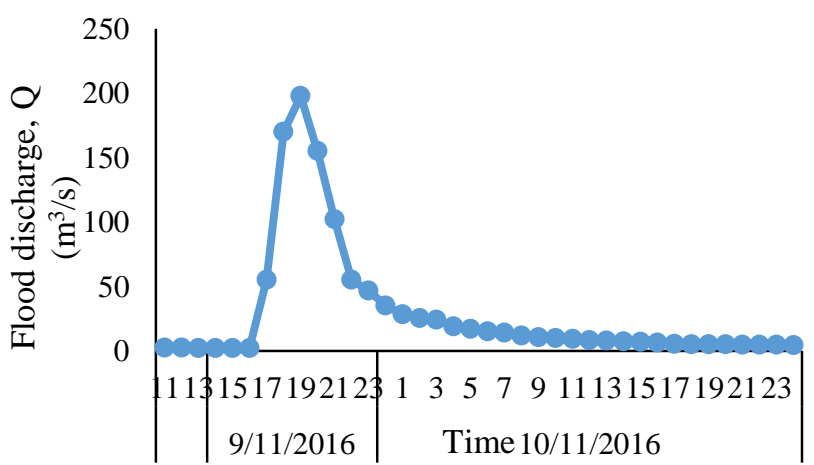

Figure 17. Flow discharge hydrograph on AWLR Dhompo

\subsection{Hydraulics Routing}

Welang River disembogues in Madura Strait, which caused the influence of tidal to the Welang River stream. Therefore, the downstream boundary condition used the tidal data that was collected from the Port Authority Office and Harbourmaster of Pasuruan year 2016. The downstream boundary condition on the calibration process used the tidal data which was adjusted with flood event on November $9^{\text {th }}, 2016$, at 11:00 until November $10^{\text {th }}, 2016$, at 24:00, as shown in
Figure 18. The downstream boundary condition on the design flood simulation was the maximum tide height data on 2016 that was 0.602 m, as shown in Figure 19.

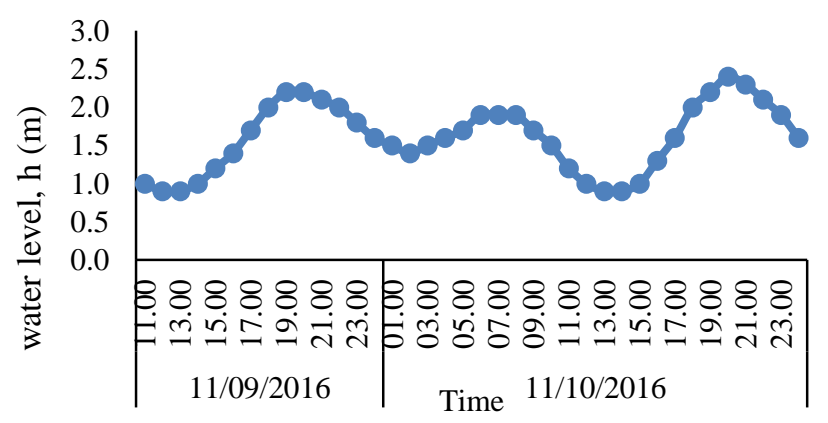

Figure 18. Downstream boundary for calibration process

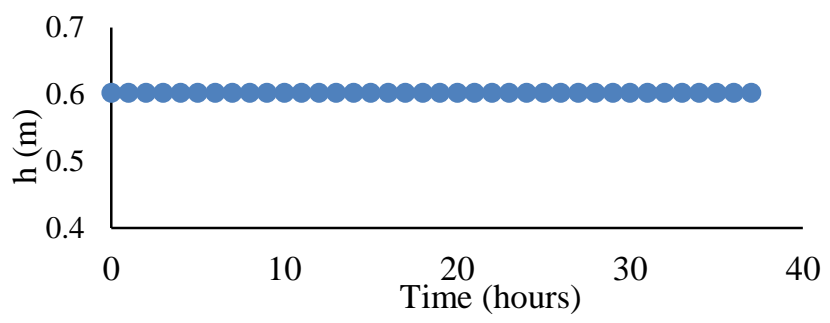

Figure 19. Downstream boundary for flood simulation

\subsection{River Geometry}

Modeling the morphology of Welang River was conducted by entering the geometry data resulted from the field measurement. The data input of cross-section cut and building geometry started from the crosssection in the most upstream area. The cross-section was started in the upstream (River Station (RS) 10716.4), precisely in AWLR Dhompo, until the estuary (RS 30.0).

The bridge modeling was of 3 units, which were the Sukorejo Bridge (RS 7434.3), Kraton Bridge (RS 5883.8), and Railway Bridge (RS 5206.9). The geometry of Welang River is presented in Figure 20.

\subsection{Calibration of Hydraulics Routing}

Water level at Kraton Bridge control point (see Figure 21 (a)) was used for n-Manning calibration. At the time of flood event, the water level was $+3.37 \mathrm{~m}$, the simulation which had closest result with the flood event was 0.026 . The result of hydraulic simulation of Welang River is shown in Figure 21(b). 


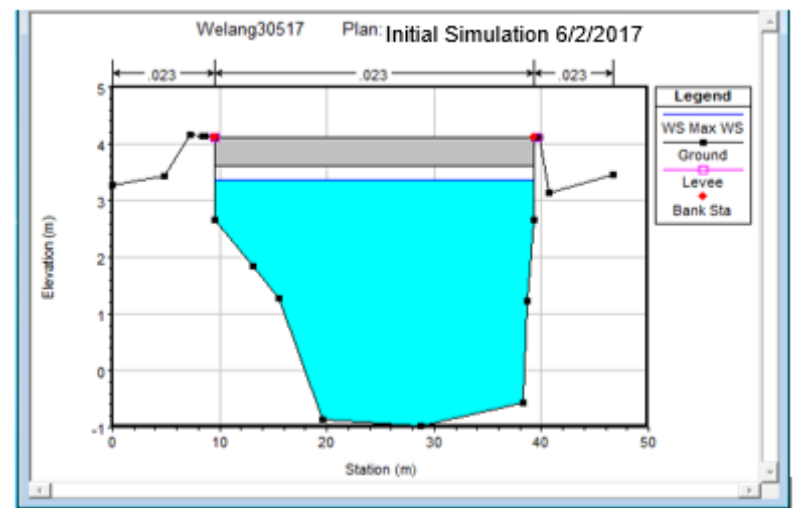

(a)

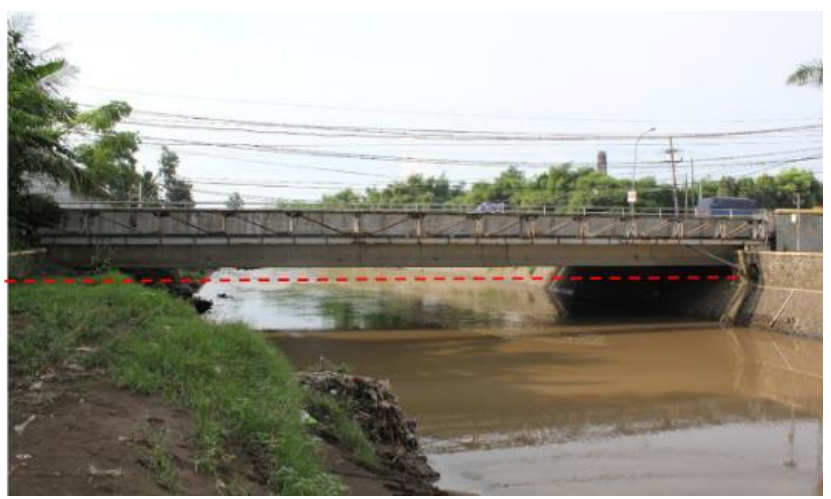

(b)

Figure 21. Results of simulation for n-Manning 0.026; (b)Water level at Kraton Bridge control point

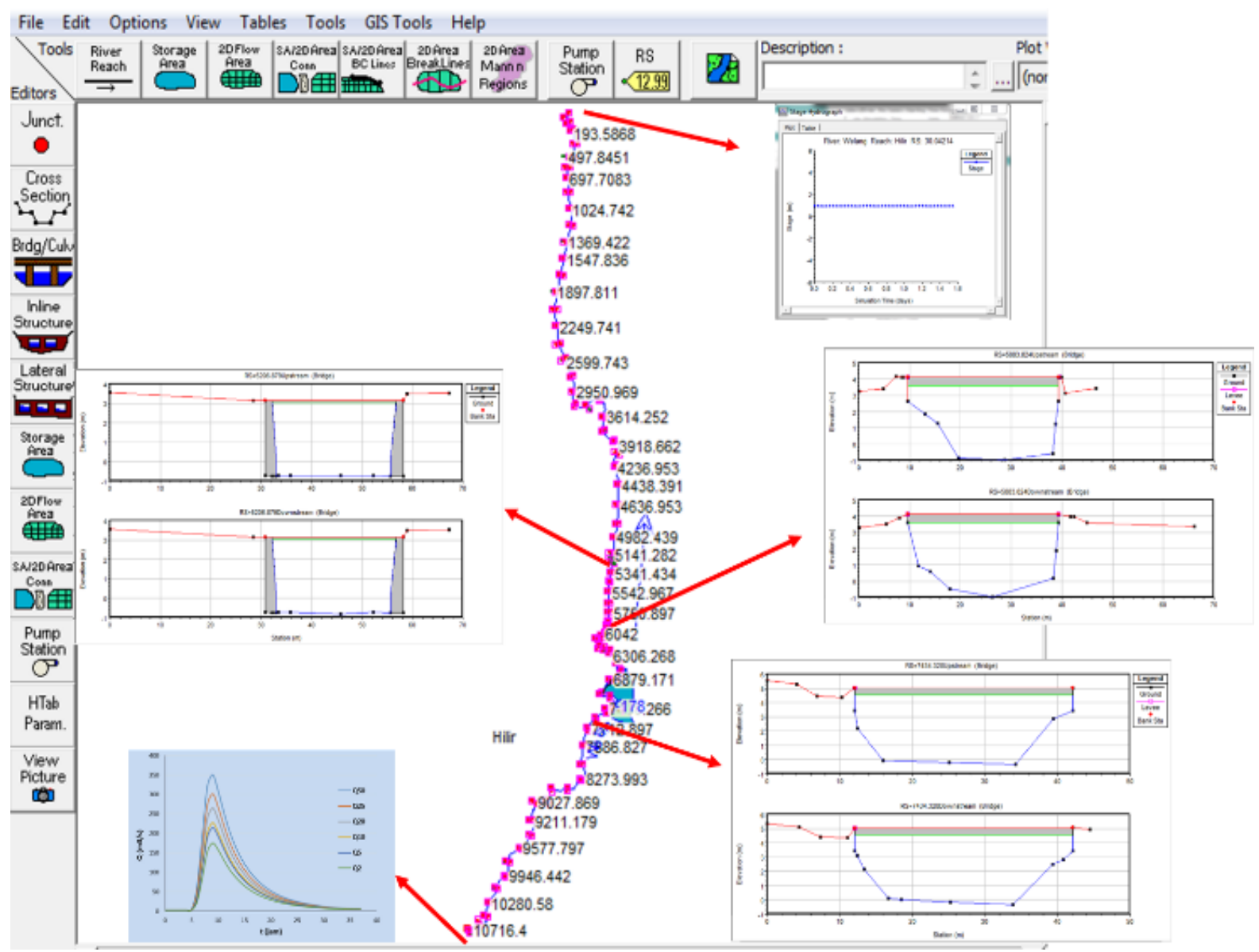

Figure 20. Scheme of Welang River modeling

\section{RESULTS AND ANALYSIS}

\subsection{Return Period of Flood}

Design flood is the flood scale used to determine the dimension of flood control structure. The hydrology analysis result with HEC-HMS would generate maximum flood discharge, flood volume, and flood hydrograph. The design flood discharge with various return periods is shown in Table 11 and Figure 22.
Table 11. Design flood peak discharge

\begin{tabular}{ll}
\hline Return period (years) & Peak discharge $\left(\mathrm{m}^{3} / \mathrm{s}\right)$ \\
\hline 2 & 175 \\
5 & 215 \\
10 & 227 \\
20 & 265 \\
25 & 302 \\
50 & 351 \\
\hline
\end{tabular}




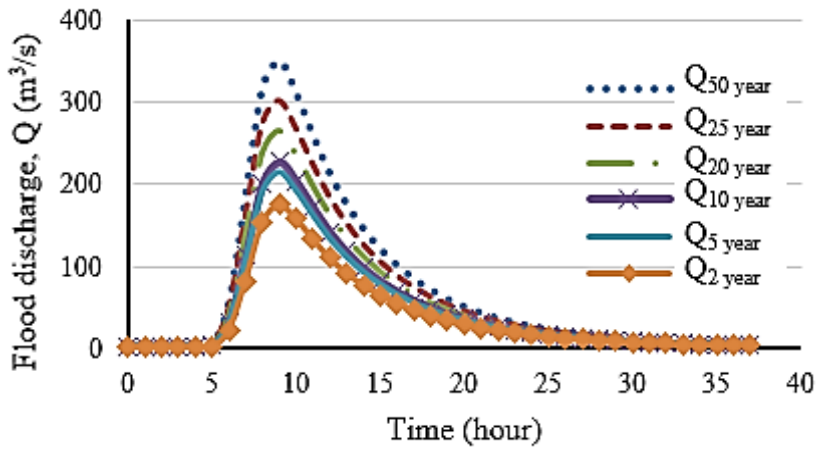

Figure 22. Flood hydrograph at various return periods

\subsection{Scenario-1 (Initial Condition)}

The first simulation was conducted at the initial condition or without retarding basin, with flood discharge of 2 years and 10 years return period. Based on the result of HEC-RAS simulation at the initial condition of flood discharge with a return period of 2 years, the runoff reached the densely populated residential area located at a distance of $497.7 \mathrm{~m}$ with maximum runoff depth of $0.66 \mathrm{~m}$. At flood discharge with a return period of 10 years, the flood inundation was at RS 6879.2 to RS 5341.4, reached a distance of $794.9 \mathrm{~m}$ with maximum runoff depth of $1.02 \mathrm{~m}$. Based on the river stream condition, the runoff location was on the river segment with low river cliff, narrow riverbed caused by sedimentation, and meandered.

\subsection{Flood Observation Control Point}

The inundation area was located at RS 7438.27 to RS 5244.1; or before the Sukorejo Bridge to the Railway Bridge, with details shown in Table 12. Every river segments were considered to represent the inundation area, specifically with lowest embankment elevation or lowest river cliff, and the river segments before and after the side spillway.

Table 12. Flood observation control points

\begin{tabular}{|c|c|c|c|c|}
\hline River Segments & $\begin{array}{l}\text { Control } \\
\text { Point }\end{array}$ & $\begin{array}{l}\text { Village/ } \\
\text { Administrative } \\
\text { Village }\end{array}$ & $\begin{array}{l}\text { Sub- } \\
\text { district }\end{array}$ & $\begin{array}{l}\text { Regency/ } \\
\text { City }\end{array}$ \\
\hline \multirow{3}{*}{$\begin{array}{l}7772.7-7368.0 \\
7368 \mathrm{ki}- \\
6976.6 \mathrm{ki}\end{array}$} & 7438.3 & \multirow{3}{*}{ Sukorejo } & \multirow{3}{*}{ Pohjentrek } & \multirow{3}{*}{ Pasuruan } \\
\hline & 7429.5 & & & \\
\hline & 7368.0 & & & \\
\hline $\begin{array}{l}6976.6 \mathrm{ki}-5543 \\
\mathrm{ki}\end{array}$ & $\begin{array}{l}6785.9 \\
5750.9 \\
\end{array}$ & Tambakrejo & Kraton & Pasuruan \\
\hline $\begin{array}{l}7368 \mathrm{ka}-5543 \\
\mathrm{ka}\end{array}$ & $\begin{array}{l}6994.3 \\
6936.7 \\
6879.2 \\
6609.3 \\
6565.2 \\
5341.4 \\
\end{array}$ & Karangketug & Gadingrejo & Pasuruan \\
\hline $\begin{array}{l}5543 \mathrm{ka}- \\
5195.7 \mathrm{ka}\end{array}$ & 5244.1 & Kraton & Kraton & Pasuruan \\
\hline
\end{tabular}

\subsection{Flood Control by Retarding Basin}

In this research, retarding basin would be used as the flood control method. The regularly flooded area along the Welang River from Sukorejo Bridge to Railway Bridge is a densely populated area, but there was a potential area of $10 \mathrm{Ha}$ to be utilized as the storage. Figure 23 presents retarding basin model using HECRAS.

The location of the retarding basin was between the RS 7434.3 and RS 5883.8 at the right side of the river, precisely in Sukorejo Village, Pohjentrek Sub-district, and Karangketug Village, Gadingrejo Sub-district. The area was in the form of paddy field, upland field, and empty land which the residents used as a spot for brickmaking. The hydraulic simulation was conducted on condition with and without retarding basin. The simulation was performed on multiple location variations of side spillway, which were on the upstream, middle, and downstream apart of the retarding basin, hereafter would be called Scenario-2, Scenario-3 and Scenario-4, with side spillway height of $3 \mathrm{~m}$ and $4 \mathrm{~m}$. Technical data of side spillway in each scenario is shown in Table 13.

Table 13. Technical data of side spillway

\begin{tabular}{lcccccc}
\hline \multirow{2}{*}{ Description } & \multicolumn{5}{c}{ Side spillway } \\
\cline { 2 - 7 } & \multicolumn{1}{c}{ Scenario 2 } & \multicolumn{2}{c}{ Scenario 3 } & \multicolumn{2}{c}{ Scenario 4 } \\
\hline Spillway height (m) & 3 & 4 & 3 & 4 & 3 & 4 \\
Spillway width (m) & 20 & 20 & 20 & 20 & 20 & 20 \\
Crest spillway el. (m) & 3.7 & 4.7 & 3.4 & 4.4 & 3.4 & 4.4 \\
Bottom spillway el. & -0.3 & -0.3 & -0.6 & -1 & -1 & -0.6 \\
(m) & 5.0 & 5.0 & 5.0 & 5.0 & 5.0 & 5.0 \\
Levee el. (m) & 0 & 0 & 0 & 0 & 0 & 0 \\
Pond bottom el. (m) & 0 & & & & & \\
\hline
\end{tabular}

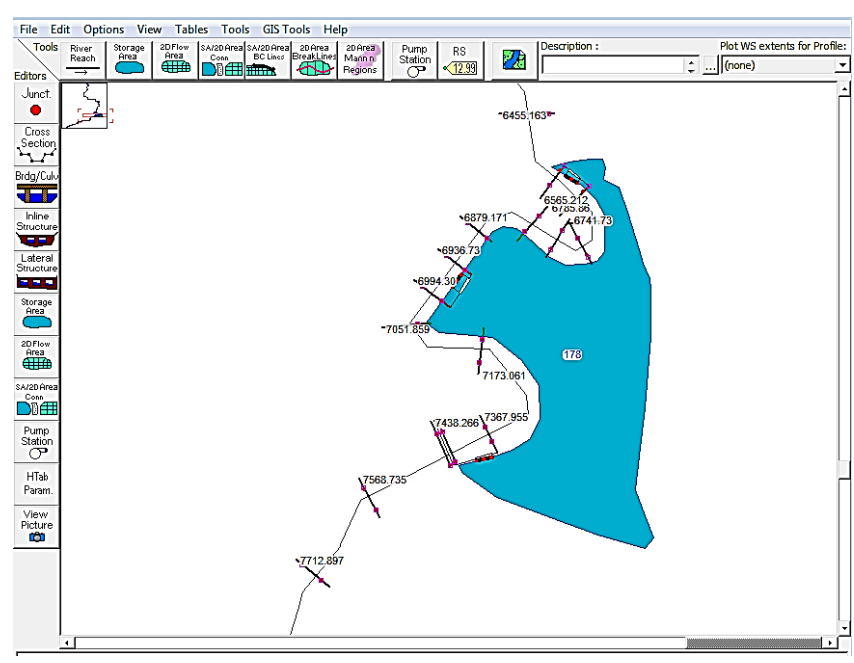

Figure 23. Retarding basin modeling

Flow discharge that enters to the retarding basin of Scenario-2 simulation is $15.55 \%$ of total discharge with a return period of 2 years. The percentage is small because the water level of the flood is mostly below the 
spillway crest elevation. Therefore, most of the discharge flowed to the downstream area. If flood discharge with a return period of 10 years occurs, the discharge that enters the retarding basin of Scenario-2 is of $20.08 \%$ from discharge in the upstream part of the retarding basin. The retarding basin function is more optimal for larger flood because the water level of the flood was higher than the crest of side spillway. The hydrograph of flood discharge with a return period of 2 and 10 years on side spillway RS 7400 are shown in Figure 24 and Figure 25.

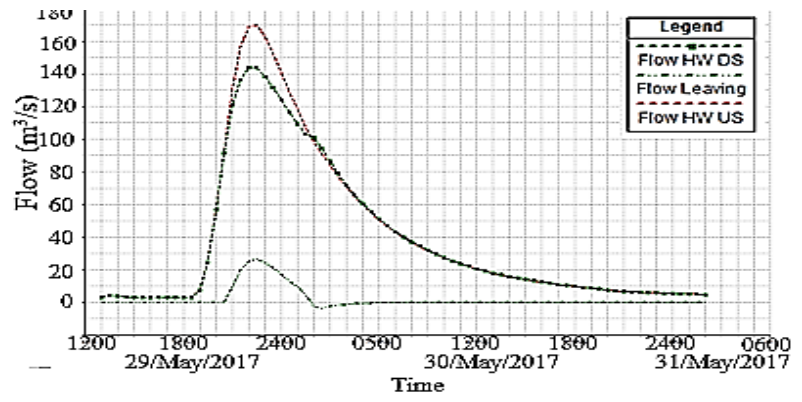

Figure 24. Water level and flow discharge over the side spillway resulted from Scenario- 2 with 2 years of return period

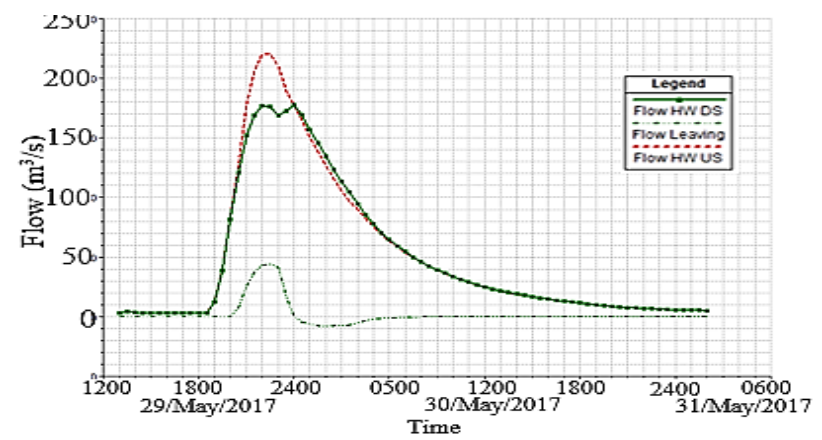

Figure 25. Water level and flow discharge over the side spillway resulted from Scenario-2 with 10 years of return period
The discharge that enters the retarding basin is also affected by the height of side spillway. The discharge that flows through the retarding basin on side spillway with $3 \mathrm{~m}$ height is $44.27 \mathrm{~m}^{3} / \mathrm{s}$. It is larger than the discharge that flows on side spillway with $4 \mathrm{~m}$ height, which is $13.18 \mathrm{~m}^{3} / \mathrm{s}$ (see Table 14).

Table 14. Recapitulation of retarding basin simulation

\begin{tabular}{lllll}
\hline Description & $\begin{array}{l}\text { WS El } \\
\mathrm{m}\end{array}$ & $\begin{array}{l}\text { Discharge } \\
\left(\mathrm{m}^{3} / \mathrm{s}\right)\end{array}$ & $\begin{array}{l}\text { Volume } \\
\left(1000 \mathrm{~m}^{3}\right)\end{array}$ \\
\hline \multirow{2}{*}{ Scenario-2 } & $\mathrm{h}=3$ & 3.95 & 44.27 & 269.16 \\
& $\mathrm{~h}=4$ & 1.04 & 13.18 & 103.68 \\
Scenario-3 & $\mathrm{h}=3$ & 3.81 & 48.03 & 241.55 \\
& $\mathrm{~h}=4$ & 1.38 & 15.66 & 138.17 \\
Scenario-4 & $\mathrm{h}=3$ & 3.62 & 42.80 & 232.68 \\
& $\mathrm{~h}=4$ & 0.88 & 11.38 & 86.74 \\
\hline
\end{tabular}

Table 15 and Table 16 shows maximum discharge and maximum water level at control points, respectively. Simulation result with retarding basin showed that on return period of 10 years, there was decreasing of discharge on Welang River at control point with water level decreasing of average $0.10 \mathrm{~m}$ to $0.42 \mathrm{~m}$, and discharge reduction of $2.15 \mathrm{~m}^{3} / \mathrm{s}$ to $42.76 \mathrm{~m}^{3} / \mathrm{s}$ (see Table 17 and Table 18).

Discharge decreasing caused by retarding basin at RS 5341.4 (control point on Karangketug Village as an area with the highest frequency of flood event); each scenario with $3 \mathrm{~m}$ side spillway were $39.63 \mathrm{~m}^{3} / \mathrm{s}, 31.83$ $\mathrm{m}^{3} / \mathrm{s}$, and $41.93 \mathrm{~m}^{3} / \mathrm{s}$. The retarding basin on each scenario with side spillway height of $4 \mathrm{~m}$ could reduce the flood discharge of 10 years return period on control point RS 5341.4 (Karangketug Village) of $14.71 \mathrm{~m}^{3} / \mathrm{s}$, $16.76 \mathrm{~m}^{3} / \mathrm{s}$, and $13.74 \mathrm{~m}^{3} / \mathrm{s}$.

Table 15. Maximum discharge on control points $\left(\mathrm{Q}_{10}\right)$

\begin{tabular}{|c|c|c|c|c|c|c|c|c|}
\hline \multirow{3}{*}{ No. } & \multirow{3}{*}{$\begin{array}{l}\text { Control point } \\
(\mathrm{RS})\end{array}$} & \multicolumn{7}{|c|}{ Maximum discharge $\left(\mathrm{m}^{3} / \mathrm{s}\right)$} \\
\hline & & \multirow{2}{*}{ Scenario 1} & \multicolumn{2}{|c|}{ Scenario 2} & \multicolumn{2}{|c|}{ Scenario 3} & \multicolumn{2}{|c|}{ Scenario 4} \\
\hline & & & $\mathrm{h}=3$ & $\mathrm{~h}=4$ & $\mathrm{~h}=3$ & $\mathrm{~h}=4$ & $\mathrm{~h}=3$ & $\mathrm{~h}=4$ \\
\hline 1 & 7438.3 & 219.65 & 178.35 & 216.74 & 187.19 & 216.73 & 215.91 & 216.17 \\
\hline 2 & 7429.5 & 219.65 & 178.45 & 216.74 & 187.19 & 216.73 & 215.91 & 216.17 \\
\hline 3 & 7368.0 & 218.86 & 178.68 & 204.96 & 186.79 & 216.71 & 215.89 & 216.13 \\
\hline 4 & 6994.3 & 218.83 & 178.47 & 204.72 & 183.45 & 216.56 & 178.56 & 215.88 \\
\hline 5 & 6936.7 & 218.03 & 178.36 & 204.69 & 186.96 & 202.47 & 178.51 & 215.84 \\
\hline 6 & 6879.2 & 218.02 & 178.36 & 204.65 & 186.72 & 202.43 & 178.23 & 215.80 \\
\hline 7 & 6785.9 & 218.01 & 178.25 & 204.55 & 186.47 & 202.33 & 178.00 & 215.68 \\
\hline 8 & 6609.3 & 218.00 & 178.14 & 204.30 & 186.46 & 202.09 & 175.24 & 215.40 \\
\hline 9 & 6565.2 & 217.98 & 178.24 & 204.25 & 186.44 & 202.04 & 175.23 & 205.43 \\
\hline 10 & 5750.9 & 217.02 & 177.56 & 203.46 & 185.47 & 201.29 & 175.13 & 204.49 \\
\hline 11 & 5341.4 & 216.96 & 177.33 & 202.25 & 185.13 & 200.20 & 175.03 & 203.22 \\
\hline 12 & 5244.1 & 216.94 & 177.22 & 202.10 & 185.03 & 200.10 & 175.02 & 203.04 \\
\hline
\end{tabular}


Table 16. Maximum water level elevation at control points

\begin{tabular}{|c|c|c|c|c|c|c|c|c|c|}
\hline \multirow{3}{*}{ No } & \multirow{3}{*}{$\begin{array}{l}\text { Control point } \\
\text { (RS) }\end{array}$} & \multicolumn{8}{|c|}{ Maximum water level elevation (m) } \\
\hline & & \multirow{2}{*}{ Scenario 1} & \multicolumn{2}{|c|}{ Scenario 2} & \multicolumn{3}{|c|}{ Scenario 3} & \multicolumn{2}{|c|}{ Scenario 4} \\
\hline & & & $\mathrm{h}=3$ & $\mathrm{~h}=4$ & $\mathrm{~h}=3$ & $\mathrm{~h}=4$ & $\mathrm{~h}=3$ & & $\mathrm{~h}=4$ \\
\hline 1 & 7438.3 & 4.46 & 4.07 & 4.29 & 4.15 & 4.30 & & 4.13 & 4.36 \\
\hline 2 & 7429.5 & 4.44 & 4.04 & 4.26 & 4.12 & 4.27 & & 4.10 & 4.33 \\
\hline 3 & 7368.0 & 4.31 & 3.92 & 4.18 & 3.99 & 4.10 & & 3.91 & 4.20 \\
\hline 4 & 6994.3 & 4.14 & 3.76 & 4.01 & 3.84 & 3.92 & & 3.72 & 4.01 \\
\hline 5 & 6936.7 & 4.11 & 3.73 & 3.98 & 3.81 & 3.96 & & 3.69 & 3.97 \\
\hline 6 & 6879.2 & 4.10 & 3.73 & 3.94 & 3.80 & 3.93 & & 3.69 & 3.93 \\
\hline 7 & 6785.9 & 3.98 & 3.62 & 4.00 & 3.69 & 3.98 & & 3.58 & 3.99 \\
\hline 8 & 6609.3 & 3.93 & 3.58 & 3.85 & 3.64 & 3.84 & & 3.55 & 3.83 \\
\hline 9 & 6565.2 & 4.00 & 3.65 & 3.81 & 3.71 & 3.79 & & 3.62 & 3.82 \\
\hline 10 & 5750.9 & 3.55 & 3.26 & 3.44 & 3.31 & 3.42 & & 3.24 & 3.45 \\
\hline 11 & 5341.4 & 3.33 & 3.01 & 3.21 & 3.07 & 3.20 & & 2.99 & 3.22 \\
\hline 12 & 5244.1 & 3.23 & 2.93 & 3.13 & 3.00 & 3.11 & & 2.92 & 3.14 \\
\hline
\end{tabular}

Table 17. Recapitulation on discharge reduction result at control point caused by retarding basin

\begin{tabular}{|c|c|c|c|c|c|c|c|c|}
\hline \multirow{3}{*}{ No } & \multirow{3}{*}{$\begin{array}{l}\text { Control point } \\
\text { (RS) }\end{array}$} & \multicolumn{7}{|c|}{ Maximum water level reduction (m) } \\
\hline & & \multirow{2}{*}{ Scenario 1} & \multicolumn{2}{|c|}{ Scenario 2} & \multicolumn{2}{|c|}{ Scenario 3} & \multicolumn{2}{|c|}{ Scenario 4} \\
\hline & & & $\mathrm{h}=3$ & $\mathrm{~h}=4$ & $\mathrm{~h}=3$ & $\mathrm{~h}=4$ & $\mathrm{~h}=3$ & $\mathrm{~h}=4$ \\
\hline 1 & 7438.3 & 0 & 0.39 & 0.17 & 0.31 & 0.16 & 0.33 & 0.10 \\
\hline 2 & 7429.5 & 0 & 0.40 & 0.18 & 0.32 & 0.17 & 0.34 & 0.11 \\
\hline 3 & 7368.0 & 0 & 0.39 & 0.13 & 0.32 & 0.21 & 0.40 & 0.11 \\
\hline 4 & 6994.3 & 0 & 0.38 & 0.13 & 0.30 & 0.22 & 0.42 & 0.13 \\
\hline 5 & 6936.7 & 0 & 0.38 & 0.13 & 0.30 & 0.15 & 0.42 & 0.14 \\
\hline 6 & 6879.2 & 0 & 0.36 & 0.13 & 0.29 & 0.14 & 0.40 & 0.14 \\
\hline 7 & 6785.9 & 0 & 0.37 & 0.13 & 0.30 & 0.15 & 0.41 & 0.14 \\
\hline 8 & 6609.3 & 0 & 0.36 & 0.13 & 0.29 & 0.14 & 0.40 & 0.15 \\
\hline 9 & 6565.2 & 0 & 0.35 & 0.12 & 0.29 & 0.14 & 0.38 & 0.11 \\
\hline 10 & 5750.9 & 0 & 0.29 & 0.11 & 0.24 & 0.13 & 0.31 & 0.10 \\
\hline 11 & 5341.4 & 0 & 0.32 & 0.12 & 0.26 & 0.13 & 0.34 & 0.11 \\
\hline 12 & 5244.1 & 0 & 0.30 & 0.10 & 0.23 & 0.12 & 0.31 & 0.09 \\
\hline
\end{tabular}

Table 18. Recapitulation on maximum water level reduction result at control points caused by retarding basin

\begin{tabular}{|c|c|c|c|c|c|c|c|c|}
\hline \multirow[t]{3}{*}{ No } & \multirow{3}{*}{$\begin{array}{l}\text { Control point } \\
(\mathrm{RS}) \\
\end{array}$} & \multicolumn{7}{|c|}{ Maximum water level reduction (\%) } \\
\hline & & \multirow[t]{2}{*}{ Scenario 1} & \multicolumn{2}{|c|}{ Scenario 2} & \multicolumn{2}{|c|}{ Scenario 3} & \multicolumn{2}{|c|}{ Scenario 4} \\
\hline & & & $\mathrm{h}=3$ & $\mathrm{~h}=4$ & $\mathrm{~h}=3$ & $\mathrm{~h}=4$ & $\mathrm{~h}=3$ & $\mathrm{~h}=4$ \\
\hline 1 & 7438.3 & 0 & 8.74 & 3.81 & 6.95 & 3.59 & 7.40 & 2.24 \\
\hline 2 & 7429.5 & 0 & 9.01 & 4.05 & 7.21 & 3.83 & 7.66 & 2.48 \\
\hline 3 & 7368.0 & 0 & 9.05 & 3.02 & 7.42 & 4.87 & 9.28 & 2.55 \\
\hline 4 & 6994.3 & 0 & 9.18 & 3.14 & 7.25 & 5.31 & 10.14 & 3.14 \\
\hline 5 & 6936.7 & 0 & 9.25 & 3.16 & 7.30 & 3.65 & 10.22 & 3.41 \\
\hline 6 & 6879.2 & 0 & 8.78 & 3.17 & 7.07 & 3.41 & 9.76 & 3.41 \\
\hline 7 & 6785.9 & 0 & 9.30 & 3.27 & 7.54 & 3.77 & 10.30 & 3.52 \\
\hline 8 & 6609.3 & 0 & 9.16 & 3.31 & 7.38 & 3.56 & 10.18 & 3.82 \\
\hline 9 & 6565.2 & 0 & 8.75 & 3.00 & 7.25 & 3.50 & 9.50 & 2.75 \\
\hline 10 & 5750.9 & 0 & 8.17 & 3.10 & 6.76 & 3.66 & 8.73 & 2.82 \\
\hline 11 & 5341.4 & 0 & 9.61 & 3.60 & 7.81 & 3.90 & 10.21 & 3.30 \\
\hline 12 & 5244.1 & 0 & 9.29 & 3.10 & 7.12 & 3.72 & 9.60 & 2.79 \\
\hline
\end{tabular}

\section{CONCLUSIONS}

Several conclusions that could be made are as follows:

a) The initial condition showed that the river stream could not drain off a discharge of 2 years return period of $175 \mathrm{~m}^{3} / \mathrm{s}$ and 10 years return period of 227 $\mathrm{m}^{3} / \mathrm{s}$, with the presence of runoff on the control point with length of $497.7 \mathrm{~m}$ and $794.9 \mathrm{~m}$.

b) Maximum runoff depth of flood with 2 and 10 years return period were $0.66 \mathrm{~m}$ and $1.02 \mathrm{~m}$, respectively.

c) Simulation result on flood routing with return period of 10 years and variation of side spillway location on upstream, middle, and downstream part 
of retarding basin showed that side spillway height of $3 \mathrm{~m}$ could reduce flood discharge with return period of 10 years at control point RS 5341.4 (Karangketug Village) by $39.63 \mathrm{~m}^{3} / \mathrm{s}, 31.83 \mathrm{~m}^{3} / \mathrm{s}$, and $41.93 \mathrm{~m}^{3} / \mathrm{s}$, while that of $4 \mathrm{~m}$ could reduce flood discharge with return period of 10 years at) by $14.71 \mathrm{~m}^{3} / \mathrm{s}, 16.76 \mathrm{~m}^{3} / \mathrm{s}$, and $13.74 \mathrm{~m}^{3} / \mathrm{s}$.

d) The distribution of rain stations on Welang Watershed was adequately good. However, the limited hourly rainfall data caused obstacles on the hydrologic modeling. Two automatic rain station compared with eight manual rain stations still could not represent the Welang Watershed condition.

\section{REFERENCES}

Ayalew,Tibebu B;Krajewski, Witold F;Mantilla, F, 2015. Insights into Expected Changes in Regulated Flood Frequencies due to the Spatial Configuration of Flood Retention Ponds. J. Hydrol. Eng., 20(10).

Brunner, G. W., 2016. HEC-RAS, River Analysis System Hydraulic Reference Manual. Davis, CA, USA: USACE, Hydrologic Engineering Center, HEC.

Chow, V. T., Maidment, D. R. \& Mays, L. W., 1988. Applied Hydrology. USA: McGraw-Hill, Inc.

Feldman, A. D., 2000. Hydrologic Modelling System HEC-HMS, Technical Reference Manual. Davis, CA, USA: USACE, Hydrologic Engineering Center, HEC.

Istiarto, 2014. Simulasi Aliran 1-Dimensi Dengan Bantuan Paket Program Hidrodinamika HEC-RAS.
[Online]

Available at: http://istiarto.staff.ugm.ac.id [Accessed 18 November 2016].

Milly, P. C. D.; Wetherald, R. T.; Dunne, K. A.; Delworth, T. L, 2002. Increasing risk of great floods in a changing climate. Nature, 415(6871), pp. 514-517.

PT.Raya Konsult, 2012. SID Pengendalian Daya Rusak Kali Welang Kabupaten Pasuruan, Surabaya: BBWS Brantas.

Safii, I., 2010. Pengaruh Perletakan Kolam Retensi Terhadap Banjir. Yogyakarta: Universitas Gadjah Mada.

Shahapure, S S; Eldho, T I; Rao, E P, 2011. Flood Simulation in an Urban Catchment of Navi Mumbai City with Detention Pond and Tidal Effects Using FEM,GIS, and Remote Sensing. J. of Waterway, Port, Coastal, Ocean Engineering, 137(6), pp. 286-299.

Sujono, J., 2014. Petunjuk Singkat Aplikasi HEC-HMS versi 4.0, Yogyakarta: Universitas Gadjah Mada.

Verstraeten, G., and Poesen, J. , 1999. The nature of small-scale flooding,muddy floods and retention pond sedimentation in central Belgium.. Geomorphology, 29(3-4), p. 275-292.

Yuwono, N., 1977. Hidrolika I. Yogyakarta: PT. Hanindita. 